\title{
Nematicidal Activity of Monoterpenoids Against the Root-Knot Nematode Meloidogyne incognita
}

\author{
Sergio Echeverrigaray, Jucimar Zacaria, and Ricardo Beltrão
}

Institute of Biotechnology, University of Caxias do Sul, Caxias do Sul 95070-560, RS, Brazil. Accepted for publication 15 October 2009.

\begin{abstract}
Echeverrigaray, S., Zacaria, J., and Beltrão, R. 2010. Nematicidal activity of monoterpenoids against the root-knot nematode Meloidogyne incognita. Phytopathology 100:199-203.

Nematicidal activity of 22 monoterpenoids were evaluated in vitro and in pot experiments. Twenty of the twenty-two monoterpenoids significantly reduced hatching, and 11 reduced $\mathrm{J} 2$ mobility of the root-knot nematode Meloidogyne incognita at a concentration of $250 \mathrm{mg} / \mathrm{liter}$. In general, compounds with hydroxyl and carbonyl groups exhibited higher

nematicidal activity than other terpenoids. Borneol, carveol, citral, geraniol, and $\alpha$-terpineol showed the highest nematicidal activity among the in vitro tested monoterpenoids. These compounds exhibited a dose dependent effect, and drastically reduced eggs hatching and $\mathrm{J} 2$ viability at low concentrations. These monoterpenoids, at 100 and $250 \mathrm{mg} / \mathrm{kg}$ concentration, diminished root galling of tomato plants in pot experiments. The results suggest that the selected monoterpenoids, and essential oils with high concentration of these compounds, are potential nematicides against Meloidogyne.
\end{abstract}

Root-knot nematodes, Meloidogyne sp., are widely distributed attacking over 2,000 different plant species, including crops and wild plants. Root-knot nematodes spend part of their life in soil either as eggs or as second-stage larvae. The latter enter the roots and establish feeding sites in susceptible hosts, inducing roots swelling with a characteristic "knotty" appearance. Root galling can drastically limits water and nutrient uptake leading to several symptoms, like malnutrition, chlorosis, and stunting, causing considerable quantitative and qualitative losses in several crop plants. Four species, $M$. incognita, $M$. javanica, $M$. arenaria, and M. hapla, are responsible for approximately $90 \%$ of the agronomical damages caused by root-knot nematodes in tropical and subtropical environments $(12,26)$.

Root-knot nematode management in agriculture includes soil fumigation, soil pasteurization, rotation with nonhost crops, and the use of resistant varieties. However, due to the environmental problems caused by nematicides, the high costs of thermal treatments, and the limited number of resistant varieties, more ecologically rational alternative systems, like biological control and natural products, are attracting attention. Nematicides of plant origin include thiocyanates, glucosides, alkaloids, phenolics, fatty acids, among others (5). Plant essential oils extracted from several plant species have been reported to have nematicidal activity and may provide potential alternative to currently used nematicides $(2,14,17-22,27)$.

Essential oils are present in many plants, particularly those designated as aromatic plants. These volatile compounds are usually extracted by steam or hydro-distillation and are used in cosmetics and medicine (3). In nature, essential oils play an important role in the protection of the plants against microorganisms, insects, nematodes, and other plants, but also as attractive of pollinators. Biological properties depend on essential oils composition, which are characterized by two or three major components at fairly high concentrations and several other components present in small or trace amounts (3). Monoter-

Corresponding author: S. Echeverrigaray; E-mail address: selaguna@ucs.br

doi:10.1094/PHYTO-100-2-0199

(C) 2010 The American Phytopathological Society penoids $\left(\mathrm{C}_{10}\right)$, formed by two isoprene units, are the most representative molecules in more than $90 \%$ of the essential oils extracted from plants (3). Essential oils and most of their constituents are classified as generally regarded as safe by the U.S. Food and Drug Administration.

In this study, we investigated the nematicidal activity of 22 monoterpenoids against the knot-root nematode $M$. incognita, in order to find potential alternatives for the control of this important agronomical pest.

\section{MATERIALS AND METHODS}

Nematode. $M$. incognita was initially isolated from Galinsoga parviflora and maintained on tomato plants (Lycopersicon esculentum cv. Santa Clara). The classification of this isolate was performed by perineal configuration, esterase electrophoretic pattern, and host range analyses.

Terpenoids. A total of 22 monoterpenoids (Table 1; Fig. 1) were used in the experiments. These terpenoids were purchased from Acros Organics (New Jersey).

In vitro experiments. Based on the results obtained by Oka et al. (17), using 1,000 mg/liter of different essential oils, the screening experiments were conducted with two terpenoid concentrations, 250 and $500 \mathrm{mg} / \mathrm{liter}$.

Egg masses of $M$. incognita were obtained from inoculated plants of tomato (L. esculentum cv. Santa Clara) roots. Eggs were extracted by the method described by Hussey and Janssen (11) using sodium hypochlorite.

For egg hatching experiments, terpenoids were diluted with $0.3 \%$ Tween 20 solution to prepare the desired concentrations according to Oka et al. (17). Terpenoids solutions (990 $\mu \mathrm{l})$ were transferred to 24 wells polystyrene tissue culture plates (St. Louis) and inoculated with $10 \mu \mathrm{l}$ of egg suspension containing approximately 100 eggs. Controls were prepared in $0.3 \%$ Tween 20. Plates were incubated at $25^{\circ} \mathrm{C}$ for 7 days, and relative hatching percentages (compared with the controls) were recorded. Tests had three replications and were repeated three times.

Second-stage juveniles (J2) were obtained by incubating egg suspensions in water. $\mathrm{J} 2$ were collected daily and maintained at 
$15^{\circ} \mathrm{C}$ (maximum of 3 days). For $\mathrm{J} 2$ mobility experiments, approximately 100 larvae were transferred to tissue culture plates containing the desired concentrations of terpenoids in $0.3 \%$ Tween 20 solutions. The plates were incubated at $25^{\circ} \mathrm{C}$ and the relative percentage of mobile $\mathbf{J} 2$ was recorded after 2 days. Tests had five replications.

All experiments followed a completely random design, and to prevent contamination by the volatilization of terpenoids, the plates were covered with polyester sealing films (Axygen Scientific, Inc.).

To confirm the nematicidal activity of monoterpenoids, immobile J2 larvae (20 to 30 larvae) were collected from the above experiments, transferred to other tissue culture plates filled with water, and monitored for $12 \mathrm{~h}$.

In vivo experiments. Terpenoids were diluted in ethanol $(1: 4)$ and mixed with $3.0 \mathrm{~kg}$ of $M$. incognita-infected sandy soil (three juveniles per gram of soil) in plastic pots at a concentration of $250 \mathrm{mg} / \mathrm{kg}$. Soil moisture was maintained at approximately 5\% (wt/wt). Pots were sealed in plastic bags and incubated at $25^{\circ} \mathrm{C}$ for 7 days. After this period, plastic bags were removed and tomato (cv. Santa Clara) seedlings with four leaves were transplanted 4 days later. Plants were placed in a growth chamber at $25 \pm 2{ }^{\circ} \mathrm{C}$ for 20 days. Seedlings were uprooted and root galling indices were recorded: $0=$ no galls, $1=1$ to $20 \%, 2=21$ to $40 \%$, $3=41$ to $60 \%, 4=61$ to $80 \%$, and $5=81$ to $100 \%$ of root galled (10). The experiment had 10 replicates and was conduced twice.

Statistical analyses. Data were subjected to analysis of variance, and means comparison was performed by the Tukey method $(P=0.05)$. Before the analysis, percentage data were transformed by $\sin ^{-1} \mathrm{X}$. Statistical analyses were made using the SPSS 10.0 computational program.

\section{RESULTS}

The effects of 22 monoterpenoids on eggs and $\mathrm{J} 2$ of $M$. incognita at concentrations of 250 and $500 \mathrm{mg} / \mathrm{liter}$ were evaluated (Table 1). Twenty monoterpenoids significantly reduced hatching of eggs at a concentration of $250 \mathrm{mg} / \mathrm{liter}$, and all the compounds tested drastically reduced hatching at $500 \mathrm{mg} / \mathrm{liter}$. However, only 11 out of 22 monoterpenoids tested gave a J2 immobility percentage of more than $50 \%$ after 2 days at a
$250 \mathrm{mg} /$ liter concentration, and seven were highly effective at J2 immobilization at $500 \mathrm{mg} / \mathrm{liter}$ (Table 1). Seven monoterpenoids-borneol, carveol, citral, geraniol, menthol, terpinen-4-ol and $\alpha$-terpineol-were highly efficient reducing more than $90 \%$ hatching and mobility at $500 \mathrm{mg} /$ liter concentration. Moreover, two compounds, citronellol and camphor, affect egg hatching and J2 mobility, respectively. High correlation between percent immobility and antihatching effect of monoterpenoids was detected $(r=$ $0.849 ; n=66 ; P=0.005)$.

Based on the above results, five terpenoids-borneol, carveol, citral, geraniol and $\alpha$-terpineol-were selected to test their effect in different concentrations. The results (Fig. 2A) showed that $\alpha$ terpineol reduced $(85 \%)$ hatching at $125 \mathrm{mg} / \mathrm{liter}$, whereas geraniol, borneol, and carveol inhibited $>75 \%$ hatching at a concentration of $250 \mathrm{mg} /$ liter (Fig. 2B). J2 mobility was inhibited by citral, geraniol, and $\alpha$-terpineol, attaining more than $80 \%$ inhibition at $60 \mathrm{mg} / \mathrm{liter}$. None of the immobile larvae recuperated their mobility after transfer to water, indicating that the monoterpenoids tested act as nematicides.

In pot experiments, the five monoterpenoids selected significantly reduced root galling (Fig. 3). Control tomato plants exhibited heavily galled roots, while plants grown on monoterpenoid-treated soils had moderate galling or absence of galls depending on the concentration used. Citral and geraniol drastically reduced the number of galls at $100 \mathrm{mg} / \mathrm{kg}$ concentration, and completely inhibited gall development at $250 \mathrm{mg} / \mathrm{kg}$. However, at the highest concentration these monoterpenoids produced signs of toxicity on tomato plants, limiting their practical use. Conversely, $\alpha$-terpineol exhibited similar efficiency and no signs of toxicity on tomato plants.

\section{DISCUSSION}

Essential oils are complex natural mixtures of volatile compounds formed by plants as secondary metabolites. Terpenes, particularly monoterpenoids, are the main constituents of aromatic plant essential oils, being responsible for most of the biological properties attributed to these plant extracts $(3,24)$. Many essential oils and some of their main constituents possess nematicidal activity against Meloidogyne and other important phytonematodes.

TABLE 1. In vitro nematicidal and antihatching activities of 22 monoterpenes on Meloidogyne incognita

\begin{tabular}{|c|c|c|c|c|}
\hline \multirow[b]{2}{*}{ Compounds } & \multicolumn{2}{|c|}{$\%$ Hatching } & \multicolumn{2}{|c|}{$\%$ J2 Mobility } \\
\hline & $250 \mathrm{mg} / \mathrm{liter}$ & $500 \mathrm{mg} / \mathrm{liter}$ & $250 \mathrm{mg} / \mathrm{liter}$ & $500 \mathrm{mg} / \mathrm{liter}$ \\
\hline Borneol & $24.2 \pm 3.3 \mathrm{hi}$ & $5.0 \pm 2.5 \mathrm{hi}$ & $27.0 \pm 5.2 \mathrm{gh}$ & $7.4 \pm 4.1 \mathrm{fgh}$ \\
\hline Bornyl acetate & $65.4 \pm 3.9 \mathrm{~d}$ & $24.0 \pm 3.5 \mathrm{cde}$ & $65.2 \pm 6.1 \mathrm{~d}$ & $24.2 \pm 7.4 \mathrm{ef}$ \\
\hline Camphor & $87.6 \pm 4.8 \mathrm{a}^{*}$ & $24.3 \pm 2.9$ cde & $58.0 \pm 5.5 \mathrm{def}$ & $9.8 \pm 5.1 \mathrm{fgh}$ \\
\hline Carveol & $22.4 \pm 4.1 \mathrm{hi}$ & $2.6 \pm 1.2 \mathrm{hi}$ & $45.8 \pm 5.3 \mathrm{efg}$ & $4.2 \pm 3.5 \mathrm{gh}$ \\
\hline 1,8-Cineole & $80.0 \pm 4.7 \mathrm{bc}$ & $39.6 \pm 3.6 b$ & $97.1 \pm 3.7 \mathrm{a} *$ & $97.4 \pm 2.8 \mathrm{a}^{*}$ \\
\hline Citral & $49.2 \pm 3.5 \mathrm{ef}$ & $7.4 \pm 4.1 \mathrm{ef}$ & $39.6 \pm 5.8 \mathrm{fgh}$ & $1.0 \pm 1.7 \mathrm{~h}$ \\
\hline Citronellal & $70.1 \pm 2.1 \mathrm{~d}$ & $22.0 \pm 2.8 \mathrm{de}$ & $63.4 \pm 6.6 \mathrm{~d}$ & $60.1 \pm 6.2 \mathrm{~d}$ \\
\hline Citronellol & $41.2 \pm 4.4 \mathrm{fg}$ & $3.6 \pm 2.8 \mathrm{hi}$ & $59.0 \pm 5.1 \mathrm{de}$ & $22.4 \pm 4.8 \mathrm{efg}$ \\
\hline Citronellyl acetate & $90.4 \pm 5.6 \mathrm{a}^{*}$ & $39.4 \pm 5.1 b$ & $97.6 \pm 1.7 \mathrm{a}^{*}$ & $96.8 \pm 2.9 \mathrm{ab}^{*}$ \\
\hline Geraniol & $27.8 \pm 2.0 \mathrm{~h}$ & $1.8 \pm 1.0 \mathrm{i}$ & $21.4 \pm 5.4 \mathrm{~h}$ & $2.8 \pm 2.2 \mathrm{gh}$ \\
\hline Limonene & $71.2 \pm 5.3 \mathrm{~d}$ & $28.6 \pm 3.1 \mathrm{~cd}$ & $97.6 \pm 2.6 \mathrm{a}$ & $96.8 \pm 3.1 \mathrm{ab}^{*}$ \\
\hline Linalool & $49.6 \pm 4.2$ ef & $24.2 \pm 3.7 \mathrm{cde}$ & $23.2 \pm 5.1 \mathrm{~h}$ & $19.8 \pm 5.1 \mathrm{efgh}$ \\
\hline Linalyl acetate & $79.8 \pm 5.1 \mathrm{bc}$ & $29.8 \pm 4.4 \mathrm{c}$ & $97.9 \pm 1.9 \mathrm{a}^{*}$ & $98.4 \pm 1.8 \mathrm{a}^{*}$ \\
\hline Menthol & $73.2 \pm 6.2 \mathrm{~cd}$ & $4.8 \pm 1.8 \mathrm{hi}$ & $42.0 \pm 7.0 \mathrm{efgh}$ & $12.8 \pm 7.6 \mathrm{fgh}$ \\
\hline Menthone & $81.2 \pm 4.9 b$ & $39.6 \pm 5.6 b$ & $86.2 \pm 5.8 \mathrm{bc}$ & $57.4 \pm 5.3 \mathrm{~d}$ \\
\hline Myrcene & $54.4 \pm 3.1 \mathrm{e}$ & $39.4 \pm 3.9 b$ & $97.2 \pm 3.6 \mathrm{a}^{*}$ & $86.8 \pm 3.0 \mathrm{ab}$ \\
\hline$\alpha$-Pinene & $51.8 \pm 5.1$ ef & $50.8 \pm 4.4 \mathrm{a}$ & $93.8 \pm 2.4 \mathrm{ab}^{*}$ & $89.4 \pm 3.3 c$ \\
\hline$\beta$-Pinene & $53.6 \pm 4.8 \mathrm{e}$ & $48.9 \pm 2.3 \mathrm{a}$ & $97.6 \pm 2.5 \mathrm{a}^{*}$ & $93.4 \pm 1.7 b c$ \\
\hline Pulegone & $32.3 \pm 2.0 \mathrm{gh}$ & $14.8 \pm 3.3 \mathrm{fg}$ & $81.6 \pm 5.4 c$ & $35.6 \pm 6.9 \mathrm{e}$ \\
\hline$\alpha$-Terpinene & $64.6 \pm 4.1 \mathrm{~d}$ & $29.8 \pm 3.7 \mathrm{c}$ & $41.6 \pm 5.2 \mathrm{efgh}$ & $35.4 \pm 4.2 \mathrm{e}$ \\
\hline Terpinen-4-ol & $14.4 \pm 2.7 \mathrm{ij}$ & $6.8 \pm 1.8 \mathrm{hi}$ & $38.2 \pm 6.1 \mathrm{gh}$ & $8.0 \pm 5.2 \mathrm{fgh}$ \\
\hline$\alpha$-Terpineol & $4.6 \pm 1.1 \mathrm{j}$ & $1.8 \pm 0.7 \mathrm{i}$ & $24.2 \pm 7.4 \mathrm{~h}$ & $6.4 \pm 5.8 \mathrm{fgh}$ \\
\hline
\end{tabular}

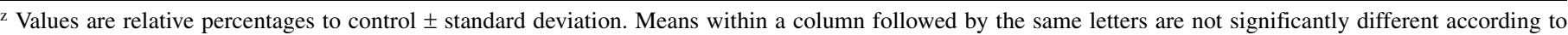
Tukey's test $(P \leq 0.05)$. * indicates values that did not differ from the controls. 
In this study, we evaluated the nematode-antagonistic activity of 22 monoterpenoids currently found as main constituents of plant essential oils, against the root knot nematode $M$. incognita. All the monoterpenoids tested exhibited antihatching activity, and most of them inhibited $\mathrm{J} 2$ mobility (Table 1). The most efficient compounds were geraniol, borneol, carveol, citral, citronellol, terpinene-4-ol, and $\alpha$-terponeol. The nematicidal activity of geraniol and citral were previously reported by Kong et al. (14) and Albuquerque et al. (2). Limonene showed antihatching activity differing from data obtained by Oka et al. (17) using the same terpenoid concentrations.

Compounds with hydroxyl or carbonyl groups were stronger than the other monoterpenoids (Table 1; Fig. 1), indicating that functional group is very important for nematicidal activity. Acetyl-esters of citronellol, linalool, and borneol were less effective than their alcoholic counterparts (Table 1), a relation observed by Park et al. (21) comparing the effect of eugenol and acetyl eugenol against the pine wood nematode Bursaphelenchus xylophilus. Moreover, the cyclic ether, 1,8-cineole, showed very low activity when compared with $\alpha$-terpineol, from which it derives.

Among acyclic alcohols, those with the hydroxyl group in $\mathrm{C} 1$ (geraniol and citronellol) were more effective than linalool, a monoterpenoid with the $-\mathrm{OH}$ group in $\mathrm{C} 3$ (Table 1; Fig. 1), and geraniol exhibited a higher nematicidal activity than citronellal, indicating that the position of the functional group and the double bond also affect monoterpenoid activity. The effect of double bond position on the nematicidal activity of terpenoids was previously reported by Park et al. (21).

A dose dependent effect was observed when increasing concentrations of five selected terpenoids were evaluated. Drastic in vitro reduction of eggs hatching and $\mathrm{J} 2$ mobility was observed even at low concentrations $(\leq 250 \mathrm{mg} / \mathrm{liter})$ of these terpenoids, indicating the potential of these monoterpenoids or essential oils with high concentration of these compounds as nematicides.

Four terpenoids (borneol, citral, geraniol, and $\alpha$-terpineol) selected from the results of the in vitro tests significantly reduced galling caused by nematodes at $100 \mathrm{mg} / \mathrm{kg}$. These results are similar to those reported by Oka et al. (17) for the essential oils of five aromatic plants. However, as reported by Walker and Melin (27) for Mentha essential oils, phytotoxic effects were detected at $250 \mathrm{mg} / \mathrm{kg}$ of citral and geraniol.

The mode of action of essential oils and terpenoids on nematodes is unclear. However, some essential oils have been reported to have genotoxic activity in Drosophila melanogaster $(8,13,16)$, to activate octopaminergic receptors $(7,15)$, and to interfere with

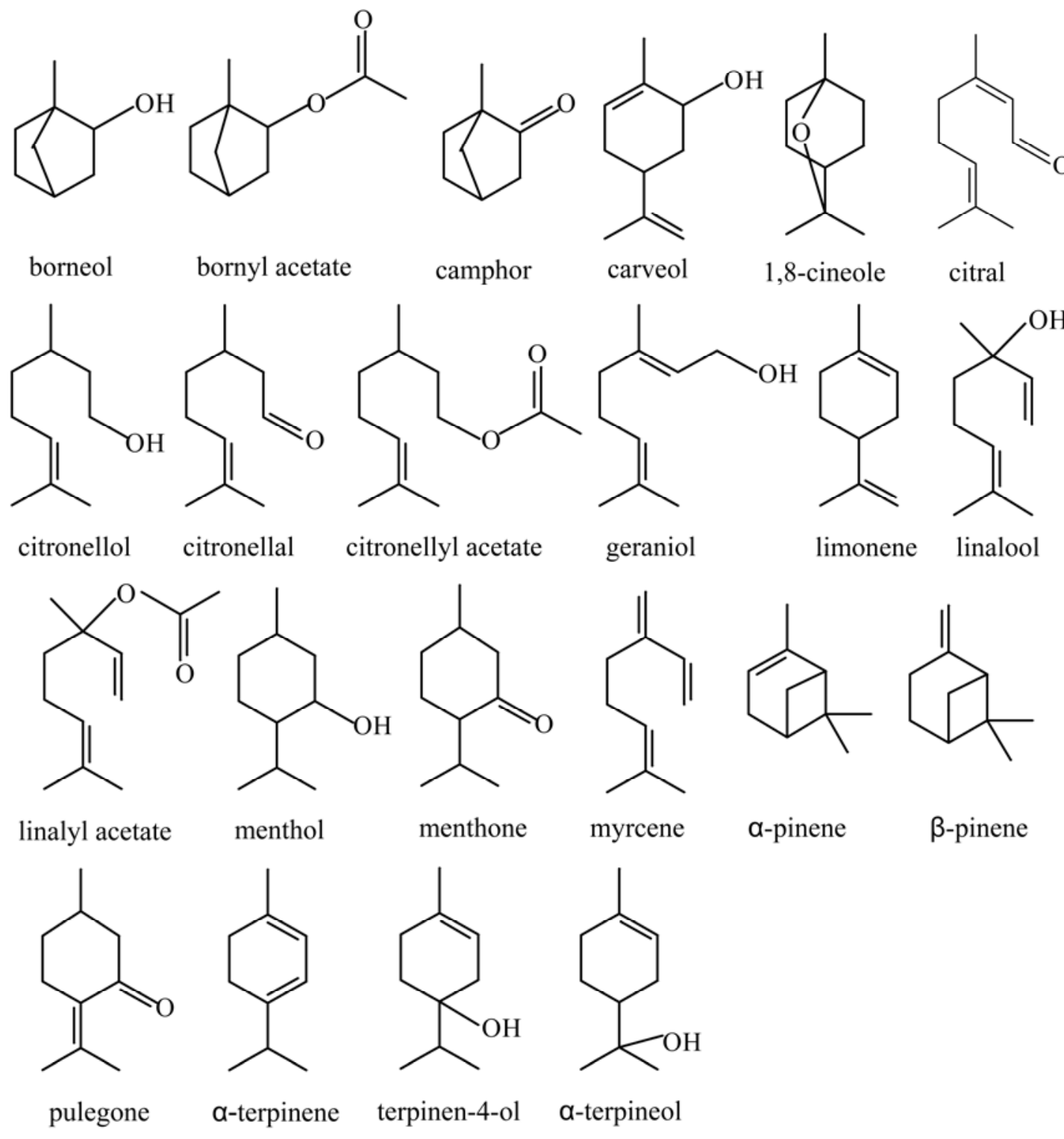

Fig. 1. Chemical structure of the 22 monoterpenoids used in this work. 
GABA receptors of insects (23). As typical lipophiles, essential oils and terpenoids interact with the cytoplasmic membrane of yeasts disrupting the structure of polysaccharides, fatty acids, and phospholipids, and provoking depolarization of the mitochondrial
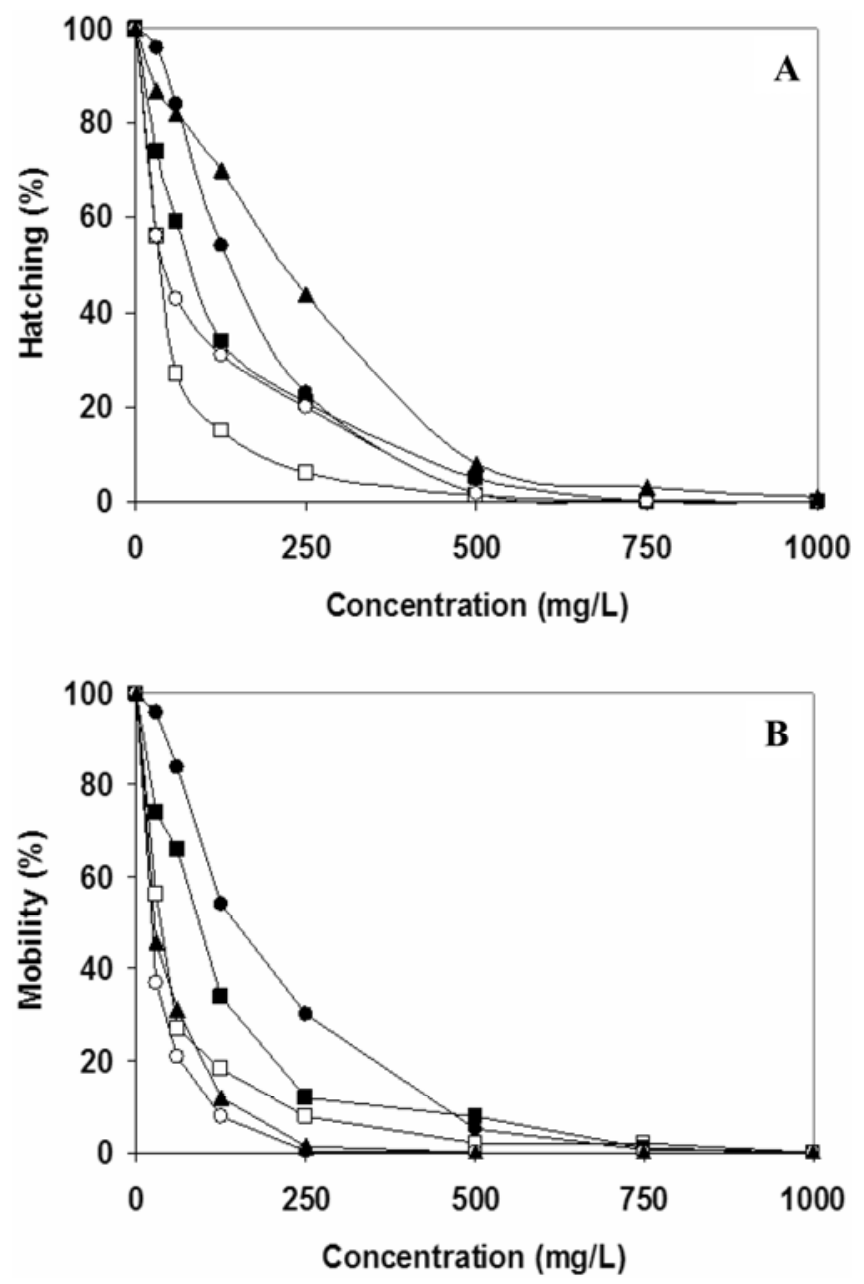

Fig. 2. Activity of selected monoterpenoids on A, hatching of eggs and $\mathbf{B}$, mobility of second-stage juveniles of Meloidogyne incognita: $\mathbf{a}$ borneol, $\bullet$ carveol, $\boldsymbol{\Delta}$ citral, $\bigcirc$ geraniol, and $\square$ terpineol. Hatching and mobility percentages were recorded after 7 and 2 days, respectively. Values are means of three replicates. membranes resulting in leakage of radicals, cytochrome $\mathrm{C}$, calcium ions, and proteins (3). In general, the in vitro cytotoxic activity of essentials oils has been attributed to the presence of phenols, aldehydes, and alcohols $(4,19)$.

Several agricultural practices involving plant extracts and plant residues, alone or in combination with physical approaches, have been proved efficient in weeds, microbial, and insect control, and some commercial natural oils are actually available for organic agriculture $(6,9)$. Plant protection against phytonematodes has been obtained by the application of essential oils $(1,18,22,27)$ or organic amendments from essential oil rich plants $(22,25)$.

In conclusion, most monoterpenoids currently found as main components of plant essential oils exhibit antihatching and/or antilarvae activity against $M$. incognita. The anti-nematode activity of terpenoids depends on their reactive groups and chemical structure. Five monoterpenoids (borneol, carveol, citral, geraniol, and $\alpha$-terpineol) efficiently inhibited hatching of eggs and J2 mobility, indicating that essential oils with high content of these compounds can be useful as natural nematicides for the control of $M$. incognita. However, the practical use of these terpenoids or essential oils require further studies on formulation, phytotoxicity, mode of action, and application.

\section{LITERATURE CITED}

1. Abo-Elyousr, K. A. M., Awad, M. E., and Gaid, M. A. A. 2009. Management of tomato root-knot nematode Meloidogyne incognita by plant extracts and essential oils. Plant Pathol. J. 25:189-192.

2. Albuquerque, M. R. J. R., Costa, S. M. O., Bandeira, P. N., Santiago, G. M. P., Andrade-Neto, M., Silveira, E. R., and Pessoa, O. D. L. 2007. Nematicidal and larvicidal activities of the essential oils from aerial parts of Pectis oligocephala and Pectis apodocephala. Baker. An. Bras. Ciências 79:209-213.

3. Bakkali, F., Averbeck, S., Averbeck, D., and Idaomar, M. 2008. Biological effects of essential oils-A review. Food Chem. Toxicol. 46:446-475.

4. Bruni, R., Médici, A., Andreotti, E., Fantin, C., Muzzoli, M., Dehesa, M., Romagnoli, C., and Sacchetti, G. 2004. Chemical composition and biological activities of Ishpingo essential oil, a traditional Ecuadorian spice from Ocotea quixos (Lam.) Kosterm. (Lauraceae) flower calices. Food Chem. 85:415-421.

5. Chitwood, D. J. 2002. Phytochemical based strategies for nematode control. Annu. Rev. Phytopathol. 34:201-225.

6. Dayan, F. E., Cantrell, C. L., and Duke, S. O. 2009. Natural products in crop protection. Biorg. Med. Chem. 17:4022-4034.

7. Enan, E. 2001. Insecticidal activity of essential oils: Octopaminergic sites of action. Comparative Biochemistry and Physiology Part C: Toxicol. Pharmacol. 130:325-337.

8. Franzios, G., Mirotsou, M., Hatziapostolou, E., Kral, J., Scouras, Z. G., and Mavragani-Tsipidou, P. 1997. Insecticidal and genotoxic activities of mint essential oils. J. Agric. Food Chem. 45:2690-2694.

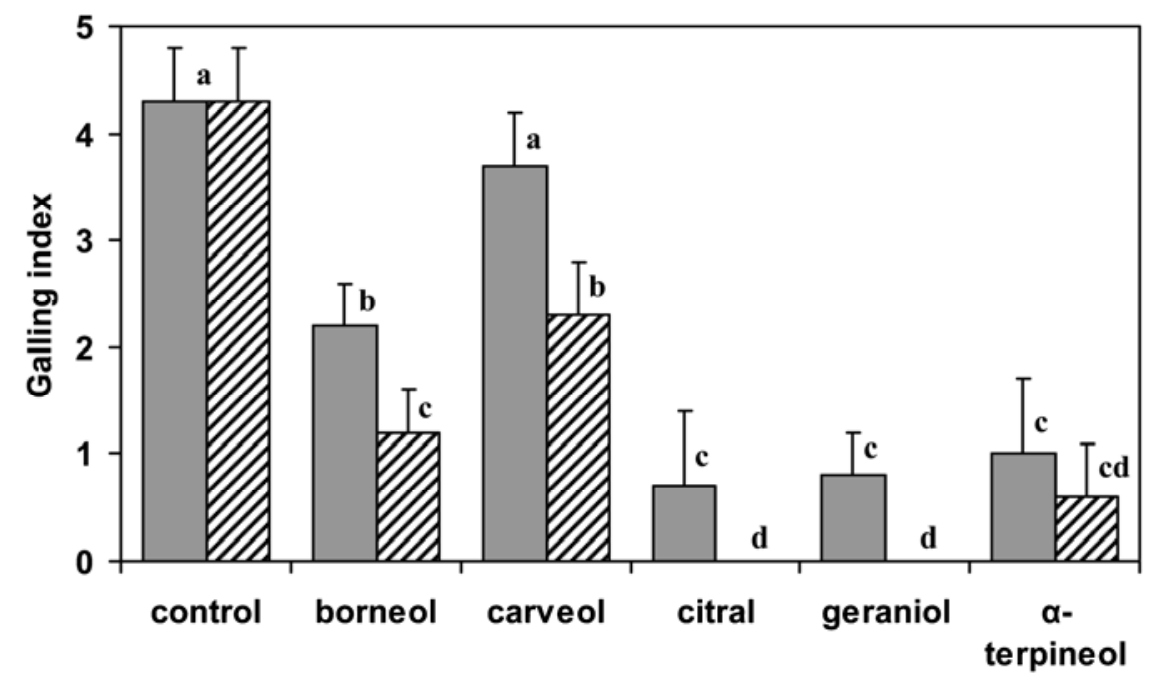

Fig. 3. Effect of soil treatment with 100 (gray bars) and $250 \mathrm{mg} / \mathrm{kg}$ (striped bars) of selected terpenoids on galling on tomato caused by Meloidogyne incognita. Values are means and standard deviations of 10 replications. Bars with the same letters are not significantly different according to Tukey's test $(P \leq 0.05)$. 
9. Gamliel, A., Austerweil, M., and Kritzman, G. 2000. Non-chemical approach to soilborne pest management-organic amendments. Crop Prot. 19:847-853.

10. Garabedian, S., and Van Gundy, S. D. 1984. Use of avermectins for the control of $M$. incognita on tomato. J. Nematol. 15:503-510.

11. Hussey, R. S., and Janssen, G. J. W. 2002. Root-knot nematodes: Meloidogyne species. Pages 43-70 in: Plant Resistance to Parasitic Nematodes. J. L. Starr, R. Cook, and J. Bridge, eds. CABI Publishing, Cambridge, MA.

12. James, W. C. 1991. Estimated losses of crops from plant pathogens. Pages 15-51 in: CRC HandBook of Pest Management in Agriculture. J. Pimentel, ed. CRC Press, Boca Raton, FL.

13. Karpouhtsis, R., Pardali, E., Feggou, E., Kokkini, S., Scouras, Z. G., and Mavragani-Tsipidou, P. 1998. Insecticidal and genotoxic activities of oregano essential oils. J. Agric. Food Chem. 46:1111-1115.

14. Kong, J. O., Park, I. K., Choi, K. S., Shin, S. C., and Ahn, Y. J. 2007. Nematicidal activities of thyme red and white oil compounds toward Bursaphelenchus xylophilus (Nematoda: Parasitaphelenchidae). J. Nematol. 39:237-242.

15. Kostyukovsky, M., Rafaeli, A., Gileadi, C., Demchenko, N., and Shaaya, E. 2002. Activation of octopaminergic receptors by essential oil constituents isolated from aromatic plants: Possible mode of action against insect pests. Pest Manag. Sci. 58:1101-1106.

16. Lazutka, J. R., Mierauskien, J., Slap, G., and Dedonyt, V. 2001. Genotoxicity of dill (Anethum graveolens L.), peppermint (Mentha piperita L.) and pine (Pinus sylvestris L.) essential oils in human lymphocytes and Drosophila melanogaster. Food Chem. Toxicol. 39:485492.

17. Oka, Y., Nacar, S., Putievsky, E., Ravid, U., Yaniv, Z., and Spiegel, Y. 2000. Nematicidal activity of essential oils and their components against the root-knot nematode. Phytopathology 90:710-715.

18. Onifade, A. K. 2007. Effect of essential oils from five Ocimum sp. on the pathogenicity of Pratylenchus brachyurus (Godfrey) in tomato. Agric. J. 2:185-191.
19. Onifade, A. K., Fatope, M. O., Deadman, M. L., and Al-Kindy, S. M. Z. 2008. Nematicidal activity of Haplophyllum tuberculatum and Plectranthus cylindraceus oils against Meloidogyne javanica. Biochem. Syst. Ecol. 36:679-683.

20. Pandey, R., Kalra, A., Tandon, S., Mehrotra, N., Singh, H. N., and Kumar, S. 2000. Essential oils as potent sources of nematicidal compounds. J. Phytopathol. 148:501-502.

21. Park, I. K., Kim, J., Lee, S. G., and Shin, S. C. 2007. Nematicidal activity of plant essential oils and components from Ajowan (Trachyspermum ammi), Allspice (Pimenta dioica) and Litsea (Litsea cubeba) essential oils against pine wood nematode (Bursaphelenchus xylophilus). J. Nematol. 39:275-279.

22. Pérez, M. P., Navas-Cortés, J. A., Pascual-Villalobos, M. J., and Castillo, P. 2003. Nematicital activity of essential oils and organic amendments from Asteraceae against root-knot nematodes. Plant Pathol. 52:395-401.

23. Priestley, C. M., Williamson, E. M., Wafford, K. A., and Sattelle, D. B. 2003. Thymol, a constituent of thyme essential oil, is a positive allosteric modulator of human $\mathrm{GABA}_{\mathrm{A}}$ receptors and a homo-oligomeric GABA receptor from Drosophila melanogaster. Brit. J. Pharmacol. 140:13631372.

24. Sacchetti, G., Maietti, S., Muzzoli, M., Scaglianti, M., Manfredini, S., Radice, M., and Bruni, R. 2005. Comparative evaluation of 11 essential oils of different origin as functional antioxidants, antiradicals and antimicrobials in food. Food Chem. 91:621-632.

25. Silva, G. S., Pereira, C. N., Bastos, C. N., and Mendoça, V. C. M. 2006. Effect of the addition of leaf residues of Piper aduncum to soil on parasitism of Meloidogyne incognita in tomato. Nematol. Bras. 30:219-222.

26. Taylor, A. L., and Sasser, J. N. 1978. Biology, identification and control of root-knot nematodes (Meloidogyne species). Department of Plant Pathology, North Carolina State University, USAID. North Carolina State University Graphics, Raleigh.

27. Walker, J. T., and Melin, J. B. 1996. Mentha $\times$ piperita, Mentha spicata and effects of their essential oils on Meloidogyne in soil. J. Nematol. 28:629-635. 